\title{
ECONOMIC ORDER QUANTITY (EOQ) ANALYSIS IN EFFORTS TO IMPROVE EFFICIENCY IN HAWAYU COFFEE \& EATERY BANDUNG
}

\author{
Ilham Fajri', Amsal Maima² \\ 1 \\ Akademi Pariwisata NHI Bandung, Bandung 40391, West Java, Indonesia \\ ${ }^{2}$ Universitas Pendidikan Indonesia, Bandung 40154, West Java, Indonesia \\ *Corresponding Author. E-mail: ilham@akparnhi.ac.id (Ilham Fajri)
}

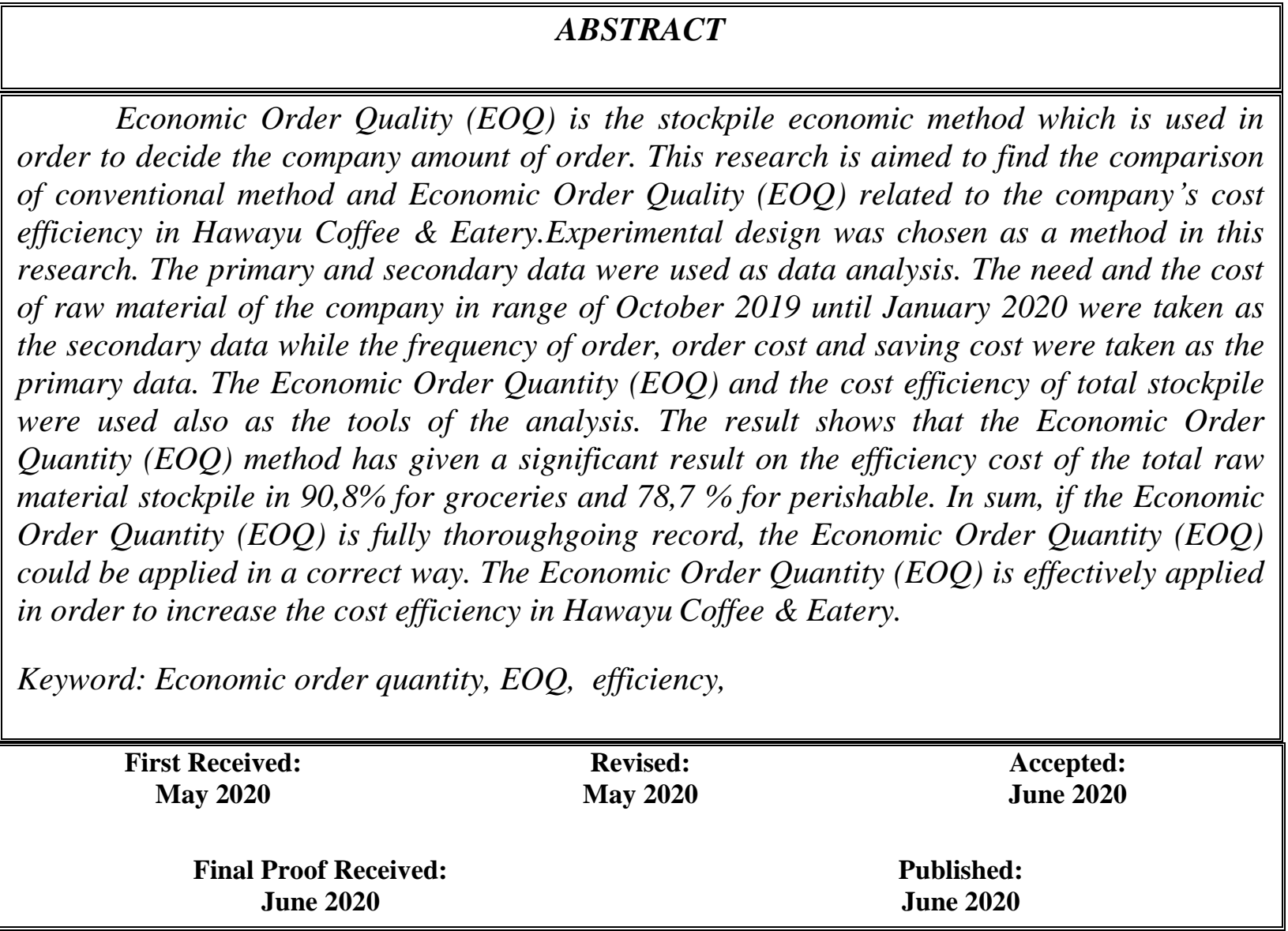




\section{INTRODUCTION}

Act No.10 of 2009, mentioned that tourism is a variety of travelling activities supported by the public, businessmen, central and regional government. Tourist attraction is the diversity of-and man-made products that become the target or destination of tourist visits

Tourism is a series of activities and services for various needs, such as tourist attractions, transportation, accommodation, etcetera that are intended to meet the needs of a person or group of people. The trip is temporary: for resting, business, or other purposes.

Bandung is one of the tourist destinations of people throughout the country. In this town people can shop and enjoy culinary with family. In fact, domestic visitors and foreign tourists also enjoy Bandung

The current development of tourism in Bandung certainly has a very positive impact on the country's economy, even in some areas, the tourism sector becomes a priority source of local income. Bandung is one of the regions that has experienced a significant increase in tourist arrivals. Domestic visits and foreign tourists in Bandung significantly increase each year so that it is very potential to develop the tourism sector, especially in culinary. One example of the development of the culinary business in Bandung City is the emergence of restaurants, cafes, foodcourts, and street vendors. The more variety of food and consumption in the city of Bandung, the more culinary business people required to make innovations to follow the current culinary trends and to meet the market demand from consumers.

Each company, either on a small, medium, or large scale, which is engaged in any field, must have a control system on the default material processor as a related record to run a production process. Recording things related to the company's operations, such as the recording of a product, the standard, the amount of production capacity used, the default material processor, the way consumers book, and other things that cannot be fully operated yet or even run by a company.

To reach the target omset of primary income, the company must have a cost control system. This system is the main task in the user account to maintain stability at a cost control. In charge management a control system is required on the supply of raw materials to the company. In a manufacturing company, especially in the field of culinary, the supply of raw materials is a major asset to a very powerful company. Provision is one of the big and sensitive issues in a company. Provision can be defined as a stock of a commodity or product to be sold or a commodity that can be used for a certain period of time. Equipment can also appear intentionally or unintentionally there may be plans for the required default agent, while unintentionally it may still be available because there are default items that have not been sold due to the low number of order or requests. Here are the importance of the required inventory control data.

a. When in a short time an item that is needed is not available, it is not possible to bring the item if it is needed persistently in a short period of time.

b. The possibility will be very small to bring goods in a short time to meet the production needs of a product. The raw materials that are out of stock can be fatal in a company, which will result in the cessation of a production process and can make the company lose its customers. On the other hand, the excess inventory or over stock can result in high costs of storage and maintenance of materials while the inventory is stored in a warehouse.

One of the cafes that must pay attention to managing the stock purchase and supply of goods is Hawayu Coffee \& Eatery. Hawayu Coffee \& Eatery is a medium-sized business engaged in culinary in Bandung since 2018. At the beginning of its operation, Hawayu Coffee \& Eatery achieved the desired target due to the rise of coffee trend in Bandung, especially students and local community. Hawayu Coffe \& Eatery has one owner and six employees and has a concept of a coffee place with a cafe atmosphere that is perfect for gathering with relatives by serving the main menu of various foods, drinks, noodles, pasta, and bread. Raw material inventory policies that must be applied in a company and the cost of these inventories can be reduced to a minimum. The decline in Hawayu Coffee \& Eatery's total revenue in the last four 
months cannot be separated from the increasing number of culinary business competition. Based on Table 1.2, in recent years, more and more have established culinary businesses in the same field, namely coffee shops so this has become the cause of increasingly fierce competition and has influenced the decline in the amount of revenue of Hawayu Coffee \& Eatery. Therefore, a strategy is needed to improve the business efficiency of Hawayu Coffee \& Eatery so that it can develop better. Before deciding to develop a company, one should pay attention to factors that can later influence the success of the company's development, both from the internal or outer side of the company. The high percentage of Cost of Inventory of goods gave impact on the income factor in Hawayu Coffe \& Eatery. Generally, the standard cost of restaurants and cafes range in $35-45 \%$. To minimize purchasing costs, in this case "Economic Order Quantity" (EOQ) method can be used. EOQ is the most economical volume or amount of purchases to be made every time a company makes a purchase (Prawirosentono, 2000). Analysis of planning using the EOQ method in a company is able to reduce the occurrence of out of stock or over stock which can disrupt the production process. a company can reduce the cost of inventory.

By using the EOQ calculation method, a minimum and maximum point of raw material inventory can be released. The most ordered inventory is only at its maximum point, that is, when the ordered product arrives. The purpose of determining the maximum point is so that the existing budget funds in the supply of materials are not excessive so there is no waste in company finances. Because when the product being ordered comes, the number of products in the company's warehouse is equal to the availability or often also referred to as safety stock. Inventory of groceries \& perishable raw material needs to support the smooth running of production. Based on table 1.4, 45 items are available, consisting of poultry, beef, dairy, cheese, sugar, pantry, pastry supplies, flours products \& rice. These materials are included in the category of groceries because they have or can be stored for a long period of time and are not easily damaged if stored properly and correctly. At Hawayu Coffee \& Eatery groceries raw materials are stored in a dry store and chiller.
Hawayu Coffe \& Eatery's raw material purchasing, planning and control systems need to be considered because they still use conventional systems, namely manual recording without theory or restaurant control in general, so companies do not know whether their stock is often overstocked and out of stock stock on raw material inventory. The case resulted in high storage and production costs. By looking at these problems, the authors are interested in conducting research.

From this description, the authors propose several problems as follows.

a. How is the system in unit inventory and raw material inventory costs applied at Hawayu Coffee \& Eatery Bandung?

b. What is the result of the Economic Order Quantity (EOQ) method on purchasing raw materials for the total cost of raw material inventory at Hawayu Coffee \& Eatery Bandung?

c. How does the result of comparison between inventory control system of the Hawayu Coffee \& Eatery conventional method and the Economic Order Quantity (EOQ) method?

\section{LITERATURE REVIEW}

\subsection{Tourism}

The following are definitions of tourism explained in some literature.

a. Tourism is a trip that is carried out for a while which is organized from one place to another to try or make a living in the place visited, but solely to enjoy the trip for sightseeing and recreation or to meet diverse desires (Yoeti, 1996: 18).

b. Tourism is a pleasant human experience and helps remove boredom from daily life that is routine and boring (Happy marpaung, 2000: 13).

c. In Law No. 10 of 2009 in Article 1 paragraph 3, tourism is a variety of tourism activities supported by various facilities and services provided by the community, entrepreneurs, government, and regional governments. 
d. Tourism is one of the new types of industries that are able to accelerate economic growth and provide employment, increase income, living standards, and stimulate other productive sectors (Nyoman, 2006).

Based on this understanding, it can be concluded that tourism is an activity or human activity in tourism activities to minimize unemployment supported by the community, entrepreneurs, and local governments.

\subsection{Understanding Restaurants}

Restaurant is one of the most popular businesses at this time, especially in Bandung. The restaurant is not only used as a place to eat, but a place to relax according to its types. According to (Marsum WA, 1993: 7) a restaurant is a place or a commercially organized building that provides good service to all guests, both in the form of food and drinks. There are three classifications of restaurants, some of which are related to the author's research.

a. Cafeteria

Cafeteria is a food service industry or restaurant that provides a variety of food or beverage menus arranged in a display so that consumers can immediately choose the desired menu. Cafeteria doesn't have many employees due to the few menus it has.

b. Coffee Shop

Coffee Shop is a place that rely on or prioritize drinks menu and only serves snacks with prices that can be afforded by various group of people. In general, the service system follows the American service which relies on speed in service.

c. Family Restaurant

Family Restaurant is a simple restaurant that provides or serves food and drinks at affordable prices, especially provided for family guests or other groups.

\subsection{Definition of Management}

Management is an activity or effort undertaken to achieve goals by using or coordinating the activities of others. " (Assauri, 2004).Heizer and Jay (2011) explained that the definition of operations management (Operations Management) is a series of activities that produce value in the form of goods and services by changing inputs into outputs. Accordingly, the average large companies in the world apply the MO (Operational Management) technique because of the awareness of the importance of the production process to increase production value and gain profits (Heizer and Reinder, 1999).

Referring to this understanding, management is a typical process consisting of planning, organizing, directing, and controlling actions taken to determine and achieve targets that have been determined through the use of human resources and other resources.

\subsection{Definition of Operation}

The term operation is often used by an organization that produces output or output, both in the form of goods or services. Operations are activities to change inputs (in the form of factors of production or operations) into outputs so that it is more useful than the original form (Subagyo, 2004).

With thai being said, it can be concluded that operations are activities that change forms by creating or adding the benefits of a service or goods used to meet human needs so that the value or benefits are higher than the original form. Meanwhile, operations management according to Fogarty from a book written by Eddy Herjanto (Herjanto, 2001) suggests that "production and operations management are processes that continuously and effectively use management functions to integrate various resources efficiently in order to achieve goals."

According to (Heizer, Jay, Barry, 2010), "operational management is a series of activities that produce value in the form of goods and services transforming inputs into outputs.

The term management contains a broader understanding so that in its development, often the term operational management uses both types of activities, both those that produce goods and services. From this explanation it can be concluded that operations management is a process of change, regulation, and coordination of inputs or resources into output in the form of goods and services effectively and efficiently so that it has added value. 


\subsection{Inventory}

Inventory is one of the most active elements in a company's operations which is continuously obtained, changed, and then resold. Most of the company's resources are also often associated with inventories that will be used in manufacturing companies. With the availability of inventory, it is expected that the company can carry out the production process according to the needs or demands of consumers. In addition, with adequate inventory in the warehouse it is also expected to facilitate production / service activities for consumers. Companies can avoid the shortage of goods, delays in the fulfillment schedule of products ordered by consumers can harm the company in this case a bad image. Eddy Herjanto explained that "inventory is material or goods stored that will be used to meet certain purposes, for example in the production or assembly process, for resale, and for parts of equipment or machinery. Inventory control systems can be defined as a set of control policies to determine the level of inventory that must be maintained "(Herjanto, 2008).

Sofjan Assauri stated that "Inventory is as an asset which includes goods belonging to the company with the intention to sell within a normal business period, or inventory of goods still in the process / production process or inventory of raw goods that are awaiting their use in a production process. "(Sofjan Assauri, 2010).

Meanwhile, the definition of inventory according to E. Richardus Indrajit \& Richardus Djokoranoto is "Inventory is a number of materials that are stored and maintained according to certain rules in the inventory so that they are always ready for use and managed in company books" (Indrajit \& Djokoranoto, 2003). Based on the definition of inventory from the experts it can be concluded that the inventory is the materials or goods used in the production process that are stored and maintained in the inventory so that it is always ready to be used to meet consumer needs.

\subsection{Types and Models of Inventories}

According to Handoko, T, (1999) based on their physical form, inventory can be divided into the following types. a. Raw Material Inventory

This means the supply of tangible goods, such as iron, wood, and other components used in the production process.

b. Inventory of Assembled Components (Purchased Parts / Components)

This means that inventories of goods consisting of components obtained from other companies can be directly assembled into a product.

c. Inventory of Auxiliary Materials or Assistance (Supplies)

This means that the inventory of goods needed in the production process, but not a part or component of finished goods.

d. Inventory in Process (Work In Process)

This means that the inventory of goods that are output from each part in the production process or has been processed into a form, but still needs to be further processed into finished goods.

\section{e. Finished Goods}

Inventory means that the inventory of goods that have been processed or processed in a factory and ready to be sold or sent to customers.

In inventory management there is a decision that must be taken by management, namely how many quantities of goods must be ordered for each procurement of inventory and when ordering goods must be re-done. The decision taken will affect the amount of fluctuations in inventory costs. The more goods ordered and stored will result in greater storage costs. Conversely, the fewer items stored will cut storage costs, but cause greater ordering costs because of the greater frequency of purchasing goods. To facilitate decision making, inventory models in inventory management according to (Rangkuti, 2004) are as follows.

\section{a. Material Acquisition Procedure}

All material purchases in a company are carried out by the purchasing department / division. To obtain a complete accountability report regarding the use of all purchased materials, a systematic procedure is required. Purchases, or uses can be carried out quickly and optimally.

b. Determination of Inventory Cost

Determination of inventory cost depends greatly on the valuation method used, namely the FEFO (First Expired First Out) method, FIFO 
(First In, First Out), LIFO (Last In, First Out) method or the Average Cost Method.

c. Storage and Use of Materials

All material purchases within a company are carried out by the purchasing department / division. To get a complete accountability report regarding the use of all purchased materials, a systematic procedure is required. Purchases or uses can be carried out precisely, quickly and optimally.

d. Inventory Valuation based on Gross Profit Method

In addition to the inventory estimation method that has been mentioned, the amount of inventory can also be assessed based on gross profit estimates. If the percentage of gross profit is known, the value of sales within a certain period can be broken down into two elements, namely: (1) Gross profit; and (2) cost of goods sold.

e. Selection of Methods for Determining

Appropriate Cost of Inventory

Before determining the choice of the appropriate cost of inventory method, it is important to compare the value of the average cost of goods per unit for the three methods above.

\subsection{Economic Order Quantity (EOQ)}

EOQ is "a way to obtain a number of goods with a minimum cost and to monitor the Ordering Cost and Carrying Cost" (Mannulang, 2005,). Then according to Martono "Economic Order Quantity (EOQ) is the number of goods purchased with a minimum inventory cost or often called the optimal order quantity". Inventory costs can be minimized by having an optimal number of orders called economic order quantities (EOQ) (Martono, 2002, p. 32)

Economic Order Quantity (EOQ) is one of the classic models in an inventory control technique. Until now, the EOQ method is still broadly used as it is easy to use. In the EOQ method, the optimal number of orders will appear at the point where the total installation cost is equal to the total holding cost (Heizer \& Render, 2010, p. 321).

Using the variables below one can determine the cost of ordering and storage in order to get the value of $\mathrm{Q} *$
Q $=$ The number of items per order

Q* $\quad=$ The optimal number of items per order

(EOQ)

D = Annual demand for supplies, in units

$\mathrm{S} \quad=$ Installation or order fees for each order

$\mathrm{H}=$ Detention or storage costs per unit per year

Annual installation fee $=$ (number of orders per year) (installation fee or order per order)

$$
\begin{aligned}
= & \frac{\text { annual demand }}{\text { order per order }} \\
= & \left(\frac{D}{Q}\right)(S) \\
= & \frac{D}{Q} S
\end{aligned}
$$

1) Annual storage costs = (average inventory level) (storage costs per unit per year) storage costs per unit per year

$=2$

$=\left(\frac{Q}{2}\right)(\mathrm{H})$

$=\frac{Q}{2} \mathrm{H}$

2) The optimal order quantity is determined when the installation fee is the same as the annual storage fee, i.e. :

$=\frac{D}{Q} s=\frac{Q}{2} \mathrm{H}$

3) To get the value of $Q *$, then do a cross product and separate $Q$ to the left of the equal sign.

$2 \mathrm{DS}=\mathrm{Q}^{2} \mathrm{H}$

$\mathrm{Q}^{2}=\frac{2 D S}{H}$

$\mathrm{Q}^{*}=\sqrt{\frac{2 D S}{H}}$

You can also specify the number of bookings you want to make throughout the year $(\mathrm{N})$ and the desired time between orders $(\mathrm{T})$, as follows:

Number of bookings desired:

$N=\frac{\text { demand }}{\text { total units ordered }}=\frac{D}{Q}$ 
Desired amount of time between orders:

$T=\frac{\text { amount of days in ayear }}{N}$

2.8. The Strengths and Weaknesses of the EOQ Method

Kartika Hendra (2009) suggests that the advantages of EOQ are:

a. Can be used to find out how much raw material should be ordered, and when an order should be made.

b. Can overcome the uncertainty of demand by having a safety stock.

c. Easily applied to the mass production process.

d. Usually used in hospitals, namely in drug supplies.

By using the EOQ method there are some shortcomings that make the production process disrupted. This happens because of the lack of close relations between the company and suppliers, the EOQ method places suppliers as temporary business partners, suppliers applying the profit-loss paradigm. Thus, the EOQ model will force companies to frequently change new suppliers.

\section{RESEARCH METHOD}

This research was conducted to analyze the supply of coffee raw materials using the Economic Order Quantity (EOQ) method. The research object employed consisted of the Independent variable, namely the Economic Order Quantity (X) method and the Dependent variable namely the cost efficiency of raw material inventory (Y). The subject of the research was the Hawayu Coffe \& Eatery company located on Jln. Sawunggaling No.2, Tamansari, Kec. Bandung Wetan, Bandung City. Hawayu Coffee \& Eatery is a culinary business that focuses on drinks made from coffee or can also be classified into a coffee shop. Hawayu also produces food and beverages ranging from planning raw materials, production, to service to consumers.

Previously, identifying a demand was a characteristic of the production and supply of a company. After knowing the amount of production and supply needs, the authors must also know how much is the demand. After that, it must be translated into an analysis of raw material planning.

This research is a modeling or application of a system that is often used in the manufacturing industry (large scale industry) into a small scale, namely the food service industry. Then, the final results of this study will be compared with the planning of raw material requirements to find out whether an EOQ method commonly used in large scale industries can be implied in small scale industries. With the form of pre-experimental design, which is one group pretest-posttest design. Thus, the results of the treatment can be known more accurately because it can compare with the conditions before being given treatment. The design can be described as follows according to (Sugiyono, 2012, p. 75).

$\mathbf{O}_{1}=\mathbf{0}_{1} \times \mathbf{0}_{2}=$ Calculation results that are already running

$\mathbf{O}_{2}=$ Results of manual calculations

Thus, the research method used is a quantitative research method by testing the hypothesis that has been proposed, namely the comparative hypothesis (difference test). booking and storage costs.

\section{RESUlts AND Discussion}

Inventory costs at Hawayu Coffee \& Eatery consist of ordering and storage costs.

\subsection{Ordering Cost}

Ordering costs are costs incurred for the supply of raw materials. The total cost of ordering in one period is obtained by the cost of ordering per order with the number of raw materials during one period. The components for ordering raw materials at Hawayu Coffee \& Eatery are administration fees, phone purchase credit and transportation costs.

The credit is used by the purchasing department for ordering raw materials. The ordering fee for each item of raw material is Rp10,404.62 per month.

\subsection{Inventory Costs}

Inventori costs exist due to the imposition of storage of raw materials in storage or warehouse. Inventory costs stored in warehouses are applied only to groceries raw materials. The components of storage costs include facility costs, damage costs, and loss costs. The inventori costs for each item of raw material is $2 \%$ of the price per item. 
The inventori costs for each item of raw material is $2 \%$ of the price per item. Determination of the number of orders can be seen in the cost of procurement of raw materials, costs associated with the procurement of raw material inventory. Amount needed or sales within a certain period of time and the price per unit of raw materials needed. Procurement of raw material requirements and ordering frequency based on the EOQ method in more detail.

Raw materials, according to the Economic Order Quantity (EOQ) method based on the dependent variables are the same as the system at Hawayu Coffee \& Eatery.

Based on the results of the EOQ calculation, the total cost of storing groceries raw materials in Hawayu Coffee \& Eatery in the period of October 2019 - January 2020 is Rp242,525.90 and the total inventory cost is Rp2,000,213.29. Meanwhile, the EOQ calculation results, the total cost of storing perishable raw materials at Hawayu Coffee \& Eatery in the October 2019-January 2020 period was Rp31,536.00 and the total inventory cost was Rp304,755.51.

Total inventory cost efficiency test is a test conducted to see how effective the mode used for the control process that has been done by the authors by testing the difference between conventional methods Hawayu Coffee \& Eatery with the EOQ method. This can be proven in the following table.

Table 1. Comparison of Total Inventory Cost Based on the Hawayu Coffee \& Eatery Conventional Method and the Economic Order Quantity (EOQ) Method

\begin{tabular}{cccccc}
\hline \multirow{2}{*}{ Material } & \multicolumn{2}{c}{ Total of Inventory Cost } & Difference & System \\
\cline { 2 - 6 } & $\begin{array}{c}\text { Company } \\
\text { Calculation } \\
(\mathrm{Rp})\end{array}$ & $\begin{array}{c}\text { EOQ } \\
\text { Calculation } \\
(\mathrm{Rp})\end{array}$ & $\begin{array}{c}\text { Differe } \\
\text { nce in } \\
\text { EOQ } \\
\text { Method } \\
\text { Results } \\
(\mathrm{Rp})\end{array}$ & $(\%)$ & $\begin{array}{c}\text { The Most } \\
\text { Economic } \\
\text { al System }\end{array}$ \\
\hline Groceries & $\begin{array}{c}8,305,0 \\
47.62\end{array}$ & $78,7 \%$ & EOQ \\
Perishable & $\begin{array}{c}3,672,906.4 \\
7\end{array}$ & $2,242,739.69$ & $\begin{array}{c}3,336,6 \\
14.96\end{array}$ & $90,8 \%$ & EOQ \\
\hline
\end{tabular}

Source: Hawayu Coffee \& Eatery processed data, 2020

After comparing the total inventory costs, it can be proven that the Economic Order Quantity (EOQ) method is more economical compared to the conventional one used by Hawayu Coffee \& Eatery.

The EOQ method provides a total inventory cost efficiency of groceries by $78.8 \%$ and perishable raw materials by $90.8 \%$.

\section{CONCLUSION}

After data collection and data processing, it can be concluded that the availability of raw materials in culinary service companies is a determining factor in the production process.

a. Unit inventory and raw material inventory costs at Hawayu Coffee \& Eatery in the period of October 2019-January 2020 for groceries consisting of 48 items and perishable raw materials consisting of 14 items. The total inventory cost is obtained from the sum of the total storage costs and the total ordering costs for one period, namely for groceries raw materials according to the company is $\mathrm{Rp}$ $10,547,787.31$ and perishable raw materials Rp 3,672.906.47.

b. The results of the Economic Order Quantity (EOQ) method in purchasing raw materials to the total cost of raw material inventory at Hawayu Coffee \& Eatery Bandung is obtained from the EOQ method. The total cost of raw material inventory that can be streamlined for groceries is $\mathrm{Rp} 2,242,739.69$ and perishable raw material is Rp336,291.51.

c. Comparison using the conventional EOQ method found in Hawayu Coffee \& Eatery in purchasing raw materials to the total efficiency of raw material inventory costs during the period October 2019-January 2020. It can be concluded that inventory cost efficiency is $78.7 \%$ for groceries and 90 raw materials $.8 \%$ for perishable raw materials.

\section{References}

Assauri, S. (2004). Manajemen Produksi dan Operasi (Manajemen). Jakarta: Lembaga Penerbit Fakultas Ekonomi Universitas Indonesia.

Handoko, T, H. (1999). Dasar - dasar Manajemen Produksi dan Operasi, Edisi 7 (Dasar-dasa). Yogyakarta: BPFE 
Heizer, Jay, and Barry Render. (2010). Operations Management. Jakarta: Salemba Empat.

Heizer, Jay, and R. (2011). Operation Management, Buku 1 edisi 9 (Operations). Jakarta: Salemba Empat.

Marpaung, H., D. S. (2000). Pengetahuan Kepariwisataan . Bandung: ALFABETA.

Marsum. (1993). Restoran dan Segala Permasalahannya. Yogyakarta: Andi Offset.

Martono, Hartito. (2002). Manajemen Keuangan. Edisi Pertama. Yogyakarta: Ekonisia

Pendit, S. Nyoman (2006). Pariwisata. Jakarta: PT. Praddnya Paramita
Prawirosentono, S. (2000). Manajemen Operasi : Analisis dan Studi Kasus. Jakarta: Bumi Aksara.

Subagyo, P. (2004). Manajemen Operasi (Manajemen). Yogyakarta: BPFE.

Sugiyono. (2012). Matode penelitian Kuantitatif, kualitatif dan $R \& D$. Bandung: Alfabeta.

Yoeti, O, A. (1996). Pengantar Ilmu Pariwisata. Bandung: Angkasa.

\section{Book}

Manullang, Marihot \& Sinaga, Dearlina. (2005). Pengantar Manajemen Keuangan. Yogyakarta: Andi Offset

\section{Rules}

Undang - Undang Republik Indonesia No.10

Tahun 2009 Tentang Kepariwisataan. 